Elena Perezva, Sergey Mironenko. Information and communications technologies as the tools of activation students' cognitive activity.

Analyzation the issues of necessity to use innovative teaching technologies, forms and methods, their phase and implementation areas to improve the level of cognitive activity of students. To make more profound knowledge of teaching methods of computer skills in IHL (Institution of Higher Learning), to develop the skills of using innovative forms of teaching in accordance with the demands of contemporaneity.

Keywords: cognitive activity, information and communications technologies (ICT), innovative methods of education.

Стаття надійшла до редакційної колегії 30.05.2017

УДК 001.891.3+37.015.31

Пипенко Ірина Сергіївна

(C) Пипенко I. С., 2017

Харківська обласна громадська організація «Культура Здоров'я»

\title{
ТЕОРЕТИКО-МЕТОДОЛОГІЧНЕ ОБГРУНТУВАННЯ ФЕНОМЕНУ «ТВОРЧИЙ ПОТЕНЦІАЛ ОСОБИСТОСТІ»
}

Розглянуто підходи до розуміння феномену творчого потенціалу особистості. Уточнено сутність поняття «творчий потениіал особистості», яке враховує сучасні теоретико-методологічні тендениії розуміння иього феномену. Встановлено значення макро- $i$ мікросочіологічних умов розвитку творчого потенціалу особистості. Ключові слова: особистість, творчість, потенціал, творчий потениіал особистості.

Проблема, іiі зв'язок із важливими науковими чи практичними завданнями. Сьогодні найважливішою характеристикою суспільства $\epsilon$ рівень розвитку творчої діяльності, створення, розповсюдження та споживання творчих знань людини. Джерелом творчих ідей, знань, вмінь людини виступає його творчий потенціал. Кожна людина за своє життя проходить тривалий шлях, під час якого розвиває свої задатки і здібності, навчається, формує компетентності, які стають підгрунтям індивідуального творчого потенціалу.

Феномен «творчий потенціал особистості» відноситься до числа найбільш складних, він незмінно привертає увагу філософів, культурологів, соціологів, антропологів, психологів, педагогів. Тому 
актуальним $є$ розгляд сучасних тенденцій теоретико-методологічного обгрунтування цього феномену.

Аналіз публікацій (виділення невирішених проблем). У сучасній науковій літературі [1-8] поняття «творчий потенціал особистості» не має однозначного тлумачення в силу різних методологічних підходів до його визначення. Вчені феномен творчого потенціалу особистості досліджують переважно 3 позицій діяльнісного, аксіологічного та інтегративного підходів. Розглянемо їх грунтовніше 3 аналізом семантичних (теоретико-методологічних) особливостей.

Каган М. С. [1] визначає структуру особистості, виходячи 3 видової будови людської діяльності, яку характеризує п’ятьма потенціалами: гносеологічним, комунікативним, аксіологічними, художнім і творчим. Творчий потенціал особистості визначається отриманими нею і самостійно виробленими вміннями і навичками, здібностями до дії, творчого і (або) руйнівному, продуктивному або репродуктивному, і мірою їх реалізації в тій чи іншій (або декількох) сфері праці, соціально-організаторської і революційно-критичної діяльності.

Риндак В. Г. розглядає творчий потенціал особистості як «систему особистісних здібностей, що дозволяють оптимально змінювати прийоми дій відповідно до нових умов, і як інтегральну цілісність природних і соціальних сил людини, що забезпечують його суб’ єктивну потребу у творчій самореалізації та саморозвитку» [2].

Таким чином, вчені розглядали феномен «творчий потенціал особистості» в рамках діяльнісного підходу - як якість, що характеризує міру можливостей особистості здійснювати діяльність творчого характеру.

Глухівська Є. А. визначає творчий потенціал особистості як «динамічну інтегративну особистісну властивість (в сукупності особистісних здібностей, знань, умінь, переконань, відносин, спрямованості), що визначає потребу, готовність і можливість творчої самореалізації і саморозвитку» [3].

На офіційному сайті Департаменту освіти і науки Київської обласної державної адміністрації [4] творчий потенціал пропонується розглядати як динамічну структуру, що включає комплекс творчих задатків, які проявляються у творчій активності особистості i обумовлена креативністю.

Богданова О. В. [5] вважає, що творчий потенціал особистості формується на основі накопиченого ним соціального досвіду, психолого-педагогічних i предметних знань, нових ідей, умінь i навичок, що дозволяють знаходити i застосовувати оригінальні 
рішення, новаторські форми і методи і тим самим удосконалювати виконання своїх професійних функцій.

Таке розуміння творчого потенціалу особистості - як набір отриманих знань, сформованих умінь і навичок, а також як здатність до дії і міру їі реалізації в певній сфері діяльності і спілкування можна віднести до аксіологічного підходу.

Кулюткин Ю. Н. [6] творчий потенціал особистості ототожнює iз ефективністю діяльності особистості в змінюваному світі, що характеризується не тільки ціннісно-смисловими структурами, які склалися у людини, понятійним апаратом мислення або методами вирішення завдань, але і деякою загальною психологічною базою, що детермінує їх. Така база, такий потенціал розвитку $є$ системним утворенням особистості, яке характеризується мотиваційними, інтелектуальними і психофізіологічними резервами розвитку: а) багатством потреб і інтересів особистості, іiі спрямованістю на все більш повну самореалізацію в різних сферах праці, пізнання i спілкування; б) рівнем розвитку інтелектуальних здібностей, що дозволяють людині ефективно вирішувати нові для нього життєві і професійні проблеми, особливо глобального характеру. Людина повинна бути відкритою по відношенню до нового; реалістично підходити до виникаючих проблем, бачити їх у всій складності, суперечливості і різноманітті. Така людина повинна також володіти широким i гнучким мисленням, бачити альтернативні шляхи вирішення і долати стереотипи, що склалися; критично аналізувати досвід, вміти робити висновки 3 минулого; володіти високою працездатністю, фізичною силою і енергією, високим рівнем розвитку психофізіологічних можливостей.

Даринська Л. А. [7] описує творчий потенціал особистості як складне інтегральне поняття, яке включає в себе природно-генетичний, соціально-особистісний i логічний компоненти, що в сукупності представляють собою знання, вміння, здібності і прагнення особистості до перетворень в різних сферах діяльності в рамках загальнолюдських норм моралі і моральності.

Моляко В. О. та Музика О. Л. [8] визначають творчий потенціал як інтегративну властивість особистості, що характеризує міру можливостей здійснювати творчу діяльність, готовність та здатність до творчої самореалізації та саморозвитку.

Ці дослідники визначають творчий потенціал особистості як інтегративну особистісну характеристику людини, яка є системним динамічним утворенням, тобто з позиції інтегративного підходу.

Стислий аналіз розглянутих підходів показує, що досить важко дати однозначне визначення такого феномену як творчий потенціал особистості. 
Ціль статті - уточнити сутність поняття «творчий потенціал особистості» на підгрунті сучасних теоретико-методологічних підходів, визначити умови розвитку творчого потенціалу особистості.

Виклад основного матеріалу, обгрунтування результатів дослідження. Уточнення поняття творчого потенціалу особистості має базуватися на чіткому термінологічному визначенні власне дефініцій «потенціал», «творчість» (похідної «творчий»), «особистість».

В етимологічному значенні термін «потенціал» походить від латинського слова potentia - сила або міць. Згідно зі словником іншомовних слів «потенціал - можливості, наявні сили, запаси, засоби, що можуть бути використані» [9, с. 673]. Таке трактування терміну «потенціал» носить загальний характер, що дозволяе його застосовувати до різних галузей науки і діяльності особистості залежно від того, про які можливості, сили, запаси і засоби йде мова.

У словнику української мови [10] творчість визначається як діяльність, пройнята елементами нового, вдосконалення, збагачення, розвитку.

Творчість може розглядатися в культурологічному та психологічному аспекті. Психологічний аспект творчості передбачає наявність у особистості задатків та здібностей, мотивів, певних компетентностей, ціннісних орієнтацій, завдяки яким створюється принципово нове, яке характеризується оригінальністю.

У класичному розумінні особистість - це сукупність стійких психологічних якостей людини, що складають його індивідуальність, тобто своєрідне поєднання індивідуальних властивостей людини, що відрізняє його від інших людей [11].

На підгрунті сучасних теоретико-методологічних підходів зробимо уточнення сутності поняття «творчий потенціал особистості».

Творчий потенціал особистості - це унікальна характеристика високо персоналізованої системи компетентностей людини, яка визначається індивідуальною та соціальною суб'єктивністю, яка забезпечує потребу в самореалізації і саморозвитку, спрямована на пошук нестандартних, оригінальних рішень 3 використанням власних ресурсів, яка дозволяє досягти особисто i соціально значущих результатів в одному або декількох видах діяльності.

Творчий потенціал особистості залежить від віку та індивідуальних особливостей особистості, фізичного, психічного, соціального, духовного здоров'я, передбачає наявність у людини певних (освітніх, професійних та ін.) здібностей, потреб, життєвої позиції, установок. Він може бути реалізований, а може залишитися i зовсім недоторканим. Це залежить від умов розвитку особистості. Такими умовами реалізації творчого потенціалу можуть виступати: макросоціологічні (соціально-економічні та соціально-політичні 


\section{Збірник наукових статей}

чинники) і мікросоціологічні (культура соціальної групи, організаційна культура, гендерні аспекти).

Висновки, перспективи. Таким чином, в рамках цієї статті стисло розглянуто ряд підходів (діяльнісний, аксіологічний, інтегративний) до розуміння феномену «творчий потенціал особистості», зроблено уточнення поняття творчого потенціалу особистості, а також встановлено значення макро- i мікросоціологічних умов його розвитку.

Подальшого дослідження потребують питання визначення критеріїв та показників формування творчого потенціалу особистості, а також розробки методик вивчення його розвитку.

\section{Література}

1. Каган М. С. Человеческая деятельность / М. С. Каган. - М. : Мысль, 1974. - 268 с.

2. Рындак В. Г. Взаимодействие процессов непрерывного образования и развития творческого потенциала учителя : дис. ... д-ра пед. наук : 13.00.01 / Рындак Валентина Григорьевна. - Челябинск, 1996. $-340 \mathrm{c}$.

3. Глуховская Е. А. Развитие творческого потенциала старшего школьника в учебной деятельности : дис. ... канд. пед. наук : 13.00.01 / Глуховская Елена Александровна. - Оренбург, 1997. - 249 с.

4. Творчий потенціал [Електронний ресурс]/ Департамент освіти і науки Київської обласної державної адміністрації. - Режим доступу : $\quad$ http://www.kyiv-oblosvita.gov.ua/osvitnya-diyalnist/84uncategorised/informatsijno-metodichni-materiali-man/1423-

psikhologichna-sut-tvorchogo-potentsialu. - Назва з титул. екрану.

5. Богданова О. В. Розвиток творчого потенціалу педагога в системі науково-методичної роботи школи [Електронний ресурс]/ О. В. Богданова, О. В. Кульчейко. - Режим доступу : http://osvita.ua/school/lessons_summary/administration/36540/. - Назва 3 титул. екрану.

6. Кулюткин Ю. Н. Изменяющийся мир и проблема развития творческого потенциала личности. Ценностно-смысловой анализ / Ю. Н. Кулюткин. - СПб. : СПбГУПМ, 2001. - 84 с.

7. Даринская Л. А. Творческий потенциал учащихся: методология, теория, практика : монография / Л. А. Даринская. - СПб., 2005. -293 c.

8. Моляко В. О. Здібності, творчість, обдарованість : теорія, методика, результати досліджень / В. О. Моляко, О. Л. Музика. Житомир : Вид-во Рута, 2006. - 320 с.

9. Словник іншомовних слів / [ред. О. С. Мельничука]. - 2-ге вид., оновл. - К. : Головна редакція УРЕ, 1985. - 968 с. 
10. Словник української мови. Академічний тлумачний словник [Електронний ресурс]. - Режим доступу : http://sum.in.ua/s/tvorchistj. Назва $з$ титул. екрану.

11. Морозов А. В. Ділова психологія. Курс лекцій [Електронний pecypc] / А. В. Морозов. - Режим доступу : http://bibliograph.com.ua/psihologia-4/84.htm. - Назва з титул. екрану.

Ирина Пипенко. Теоретико-методологическое обоснование феномена «творческий потенциал личности».

Рассмотрен подход к пониманию феномена творческого потенциала личности. Уточнена сущность понятия «творческий потенциал личности», которое учитывает современные теоретикометодологические тенденции этого феномена. Установлено значение макро- и микросочиологических условий развития творческого потенциала личности.

Ключевые слова: личность, творчество, потенциал, творческий потенциал личности.

Iryna Pypenko. Theoretical and methodological substantiation of the phenomenon «creative potential of personality».

Approaches to understanding the phenomenon of creative potential of personality have been considered. The essence of the concept "creative potential of personality" have been clarified, it takes into account the modern theoretical and methodological tendencies of this phenomenon. The importance of macro- and microsociological conditions for the development of the creative potential of the individual have been established.

Keywords: personality, creativity, potential, creative potential of personality.

Стаття надійшла до редакційної колегії 17.04.2017

УДК 378.014.25:341.24

Поліщук Валерій Миколайович

СПоліщук В. М., 2017

Національний університет «Львівська політехніка»

\section{ОСОБИСТІСТЬ ВЧЕНОГО І СУБ'ЄКТИВНІ ДИРЕКТИВНІ ВИКЛИКИ}

Аналізуються типові директивні виклики у вищій школі, які становлять реальну чи потенційну загрозу для формування творчої особистості вченого. Актуалізується необхідність подолання суспільних авторитарних традицій для упередження несприятливих навчально-виховних проблем. 